Journal of Islamic Economics and Finance Studies

Volume 2, No. 2 (December, 2021), pp. 162-173

DOI. http://dx.doi.org/10.47700/jiefes.v2i2.3552

ISSN $2723-6730$ (Print)

ISSN 2723 - 6749 (Online)

\title{
Peran Perguruan Tinggi Pesantren dalam Implementasi Literasi Ekonomi
}

\author{
Ahmad Lukman Nugraha* \\ Universitas Darussalam Gontor, Pascasarjana Universitas Islam Negeri Sunan Gunung Djati Bandung \\ ahmad.lukman.n90@gmail.com
}

Adib Susilo

Universitas Darussalam Gontor, Postgraduate Program of International Islamic University Malaysia adib.susilo27@gmail.com

Chaerul Rochman

Universitas Islam Negeri Sunan Gunung Djati Bandung

chaerulrochman99@uinsgd.ac.id

*Penulis korespondensi

Diterima: 16 Oktober 2021 | Direvisi: 8 November 2021 | Dipublikasi: 25 Desember 2021

\begin{abstract}
This study aims to determine the role of Islamic boarding schools in the application of economic literacy. The research method used is descriptive qualitative. The object of this research is Darussalam Gontor University. The results of this study indicate that Islamic boarding schools in implementing economic literacy carry out several functions; 1) as an educational institution that changes the economic orientation of the community which was originally intended to satisfy wants, to become "sufficient" by meeting needs, 2) as an educational institution that changes a consumptive lifestyle into a moderate lifestyle, 3) as an educational institution that frames human economic activities in the framework of ta'abbudi (worship) which was originally limited to the framework of meeting physical needs, 4) as an educational institution that changes its profit and utility orientation, to an orientation to maximize maslahah, 5) as an educational institution that applies forced learning methods, and finally could be because they are used to it, 6) as an educational institution that applies economic literacy not limited to academic aspects, but non-academic aspects
\end{abstract}

Keywords: Consumption Behavior; Economic Literacy; Islamic economics; Pesantren; University

\begin{abstract}
Abstrak
Penelitian ini bertujuan untuk mengetahui peran universitas pesantren dalam penerapan literasi ekonomi. Metode penelitian yang digunakan adalah deskriptif kualitatif. Objek penelitian ini adalah Universitas Darussalam Gontor. Hasil penelitian ini menunjukkan bahwa universitas pesantren dalam pelaksanaan literasi ekonomi menjalankan beberapa fungsi; 1) sebagai lembaga pendidikan yang mengubah orientasi ekonomi masyarakat yang semula dimaksudkan untuk memuaskan keinginan, menjadi "cukup" dengan memenuhi kebutuhan, 2) sebagai institusi pendidikan yang mengubah gaya hidup konsumtif menjadi gaya hidup moderat, 3) sebagai lembaga pendidikan yang membingkai kegiatan ekonomi manusia modern dalam kerangka ta'abbudi (ibadah) yang semula terbatas pada kerangka pemenuhan kebutuhan fisik, 4) sebagai lembaga pendidikan yang mengubah orientasi berorientasi keuntungan dan utilitas, menjadi orientasi memaksimalkan maslahah, 5) sebagai institusi pendidikan yang menerapkan metode pembelajaran secara paksa, dan akhirnya bisa karena mereka sudah terbiasa, 6) sebagai lembaga pendidikan yang menerapkan literasi ekonomi tidak terbatas pada aspek akademik, tetapi aspek non-akademik.
\end{abstract}

Kata kunci: Ekonomi Islam; Literasi Ekonomi; Perilaku Konsumsi; Perguruan Tinggi; Pesantren 


\section{PENDAHULUAN}

Indonesia merupakan negara berkembang yang telah merdeka 74 tahun yang lalu. Akan tetapi di sisi lain, Indonesia masih dinyatakan belum merdeka di berbagai bidang dalam lini kehidupan. Bidang yang sangat strategis dalam keadaan ini adalah literasi dalam masalah ekonomi. Kajian literasi menjadi salah satu aspek bidang tersebut, seperti yang bisa dirasakan saat ini dan telah ditelaah dalam berbagai sumber yang meneliti tingkat literasi dunia (Padmarini, 2002).

Central Connecticut State University United States merilis data yang menyatakan Indonesia berada pada peringkat ke-60 dari 61 negara yang diteliti. Ranking lima besar dari penelitian tersebut diduduki oleh negara kawasan Skandinavia, yakni Finlandia, Norwegia, Islandia, Denmark, Swedia. Sedangkan posisi ke-6 diraih oleh Swiss. Botswana yang merupakan negara yang berada di Afrika bagian selatan, dengan tata letak terkurung oleh daratan bekas jajahan Britania Raya, menduduki posisi paling akhir tepat setelah Indonesia (Miller \& McKenna, 2016). UNESCO menyebutkan minat baca di Indonesia hanya sekitar 0,001 . Begitu pula dengan tingkat literasi di Indonesia yang hanya berada pada rangking 64 dari 65 negara yang disurvei. Fakta memprihatinkan lainnya adalah tingkat membaca siswa Indonesia hanya menempati urutan 57 dari 65 negara (Puspita \& Irwansyah, 2018).

Kementerian Koordinator Bidang Pembangunan Manusia dan Kebudayaan menunjukkan rata-rata masyarakat Indonesia sangat minim dalam ketertarikan membaca buku, yakni tiga sampai empat kali dalam seminggu dan hanya menghabiskan waktu sekitar 30-60 menit. Total keseluruhan buku yang dapat diselesaikan dalam setahun pun hanya sekitar lima hingga sembilan buku (Prayogo, 2020). Dari data di atas, kesadaran masyarakat dalam memahami serta menerapkan makna dari literasi masih sangat minim, sehingga perlu adanya kesadaran. Keterpurukan sebuah negara akibat kurangnya literasi ekonomi masyarakat memiliki dampak buruk yang besar salah satunya yakni tingkat konsumsi yang tinggi namun masyarakat kurang mampu mengelola serta memproduksi suatu barang yang bernilai.

Literasi ekonomi sangat berperan penting dalam mengatur keinginan manusia yang tergolong tidak mudah puas (Margaretha \& Pambudhi, 2015). Mayoritas masyarakat di negara berkembang tidak begitu memperhatikan bagaimana dan apa yang akan terjadi di masa depan. Mereka lebih memilih untuk menikmati dan berlomba-lomba dalam mencapai apa yang mereka inginkan namun terkadang melupakan batasan-batasan dalam memenuhi kebutuhan hidup (hedonisme). Tidak hanya itu mereka juga melupakan kebutuhan yang harusnya layak untuk dipenuhi. Hasil survei of Wallat (Kadence International) dalam Amalia menyebutkan bahwa terdapat 28 persen dari masyarakat Indonesia yang tercatat memiliki pengeluaran lebih besar dari perolehan pendapatan, sehingga meneybabkan defisit belanja sebesar 35 persen (Amalia, 2017). Artinya anggaran belanja yang dikeluarkan lebih besar dari penghasilan. Oleh karenanya, hampir seluruh pendapatan dihabiskan 
untuk konsumsi, bahkan mereka tidak memiliki tabungan. Konsumtif merupakan perilaku seseorang dengan keinginan untuk membeli barang-barang yang kurang bahkan tidak diperlukan hanya karena untuk memuaskan keinginan pribadi sehingga tidak bisa membedakan antara keinginan dan kebutuhan. Perilaku konsumtif dapat dilihat dari kecenderungan sesorang untuk berbelanja yang terus meningkat.

Fitrah manusia sebagai mahkluk hidup memang ditakdirkan untuk mengkonsumsi sesuatu demi mempertahankan kehidupannya, namun masalah yang sedang dialami kebanyakan masyarakat terutama di negara berkembang yakni tingkat konsumsi yang sangat tinggi namun kurang memahami literasi ekonomi. Bank Indonesia (2020) melaporkan indeks literasi ekonomi Islam di Indonesia sebesar 16,3 persen, sedangkan literasi ekonomi nasional sebesar 38,03 persen. Penulis melihat kurangnya literasi ekonomi Islam yang masih jauh di bawah 20 persen, sedangkan perbankan syariah sudah berumur lebih dari 30 tahun berada di Indonesia. Pada artikel ini, penulis ingin menggali peran perguruan tinggi pesantren dalam penerapan literasi ekonomi, sehingga mampu menjadi model pengembangan ekonomi Islam di perguruan tinggi pesantren lainnya khususnya, dan masyarakat Indonesia pada umumnya.

Pesantren merupakan salah satu lembaga pendidikan paling tua di Indonesia (Nugraha, 2018). Nasir dalam Priyatna (2017) mendefinisikan pesantren sebagai lembaga keagamaan yang memberikan pendidikan dan pengajaran serta mengembangan dan menyebarkan ilmu agama Islam (Priyatna, 2017). Pendidikan pesantren tidak lepas dari keseharian, sehingga pesantren mampu bertahan dalam pembaharuan model pendidikan. Pesantren mendidik para peserta didiknya melalui pelbagai aspek, seperti ekonomi, sosial, budaya, dan agama. Semua kegiatan di pesantren menjadikan santrinya menguasai dan "literated" terhadap berbagai permasalahan di masyarakat kelak (Basyit, 2017; Ma'arif, 2011). Beberapa pesantren saat ini juga sudah memiliki perguruan tinggi. Salah satu ciri Perguruan tinggi pesantren adalah mahasiswa dan dosen berasrama dan tinggal di dalam kampus. Keadaan ini merupakan hal unik yang berbeda dari perguruan tinggi lainnya (Rizal et al., 2020). Perguruan tinggi pesantren merupakan pengembangan dari kemandirian pesantren dalam pengembangan keilmuan agama, sosial dan ekonomi. Literasi ekonomi merupakan salah satu aspek yang menjadi fokus kajian keseharian dalam lingkup pesantren.

Kebaruan yang diangkat pada penelitian ini adalah analisis mendalam dengan pendekatan kualitatif tentang bagaimana lembaga pendidikan keagamaan berperan dalam peningkatan literasi ekonomi. Penulis ingin mengkaji terkait peran perguruan tinggi pesantren dalam menanamkan literasi ekonomi dan mengubah orientasi mereka yang pada tahapannya akan mengubah gaya hidup mahasiswa. Sistem perguruan tinggi pesantren memiliki peran penting dalam peningkatan literasi mahasiswanya. Artikel ini bertujuan untuk menganalisis bagaimana peran perguruan tinggi pesantren dalam menerapkan literasi ekonomi. 


\section{TINJAUAN PUSTAKA}

\section{Literasi Ekonomi}

Kamus Besar Bahasa Indonesia (KBBI) edisi V mencantumkan dua pengertian literasi, 1) kesanggupan untuk menulis dan membaca; 2) wawasan dalam bidang atau aktivitas tertentu. Dalam arti lain, literasi sering terkait dengan penggunaan huruf untuk melambangkan bunyi atau kata (Badan Pengembangan dan Pembinaan Bahasa, 2017). Dalam bahasa Indonesia, kata literasi merupakan interpretasi dari kata literacy yang berasal dari bahasa Inggris. Pada dasarnya, literasi dalam istilah yang sederhana merupakan "melek aksara" atau "keberaksaraan". Namun, perkembangan ilmu pengetahuan dan teknologi menyebabkan istilah literasi lebih populer dibanding istilah "keberaksaraan". Literasi seakan sudah menjadi roh ilmu pengetahuan, baik dalam lingkungan formal maupun non-formal (Romdhoni, 2013).

PIRLS 2006 dalam Saifuddin \& Safitri (2015) menyatakan bahwa literasi dipahami sebagai seperangkat kemampuan dalam mengolah informasi, baik dalam mengurai dan memahami bahan bacaan sekolah (Saifudin \& Safitri, 2015). Lebih lanjut literasi adalah inti atau pusat dari kemampuan siswa untuk belajar dan berhasil dalam sekolah dan sesudahnya, jadi meskipun latar belakang siswa bermacam-macam pemerintah harus mengusahakan mereka semua mendapatkan literasi yang memadai untuk mampu menghadapi tantangan masa depan (Khomsiyatun, 2018).

Education Development Center (EDC) menyatakan bahwa literasi bukan hanya kemampuan membaca dan menulis semata (Sugrue, 2017). Literasi adalah keterampilan individu untuk menngunakan segenap potensi dan kemampuan yang dimiliki dalam hidupnya. National Institute for Literacy mendefinisikan literasi sebagai kemampuan individu dalam membaca, menulis, bertutur kata, berhitung dan memecahkan masalah pada tingkat keahlian yang dibutuhkan dalam kehidupan baik pada pekerjaan, keluarga dan masyarakat (Reder, 2010).

Menurut UNESCO, literasi seseorang sangat dipengaruh oleh riset akademik, lembaga, konteks nasional, nilai-nilai kebudayaan, dan juga pengalaman (Literacy Rates Continue to Rise from One Generation to the Next, 2017). Ringkasnya, literasi adalah kemampuan untuk mengetahui, memahami dan melakukan apa yang dimengerti dan diketahui.

Sementara itu, literasi ekonomi merupakan wahana yang berguna untuk merubah karakter dari kurang cerdas menjadi cerdas, seperti bagaimana memanfaatkan pendapatan untuk menabung, berinvestasi, perlindungan dan memenuhi kebutuhan hidup (Sina, 2012). Beberapa riset membuktikan bahwa literasi ekonomi dapat mengurangi perilaku konsumsi mahasiswa yang belebihan. Seperti yang diungkapkan Budiwati dalam Nugraha (2019), rendahnya literasi ekonomi berdampak terhadap perilaku konsumsi konsumen (Nugraha et al., 2019). Pernyataan tersebut sejalan dengan pendapat Gary H. Stern, Presiden Federal Reserve Bank of Minneapolis menjelaskan bahwa literasi ekonomi sangat penting 
untuk menunjukkan ukuran apakah orang memahami kekuatan yang secara signifikan mempengaruhi kualitas hidup mereka (Stern, 2002). Jappelli mengungkapkan bahwa literasi ekonomi penting untuk menetapkan keputusan tentang bagaimana berinvestasi, berapa banyak piutang yang tepat di pasar uang, dan bagaimana memahami konsekuensi atas stabilitas ekonomi secara keseluruhan (Jappelli, 2010).

Dalam pandangan lainnya, Mathews menyebutkan literasi ekonomi adalah gambaran kemampuan individu untuk mengetahui dan menggunakan konsep dasar ekonomi dan cara berfikir ekonomi untuk meningkatkan kesejahteraan, misalnya, mengetahui bahwa pada saat inflasi, uang menjadi tidak bernilai (Mathews et al., 1986). Menurut Vanum dkk dalam Povi, menyatakan literasi ekonomi terdiri dari berbagai pengetahuan dan kompetensi yang memungkinkan seseorang untuk meningkatkan kemampuan dalam mengambil keputusan pribadi dan sosial tentang berbagai masalah ekonomi yang dihadapi (Amelia, 2018). Burjhardt dalam Kusniawati (2016) menjelaskan literasi ekonomi adalah kemampuan untuk mengidentifikasi masalah, biaya dan manfaat ekonomi lainnya, menganalisis motivasi untuk bekerja dalam situasi ekonomi, memeriksa konsekuensi dari perubahan kondisi ekonomi dan kebijakan publik, mengumpulkan dan menyusun bukti ekonomi, dan menimbang biaya dan manfaat (Kusniawati, 2016). Penulis menyimpulkan bahwa pengertian literasi ekonomi adalah kemampuan individu atau kelompok dalam mengidentifikasi masalah ekonomi, mengalanisis solusi, dan membuat keputusan yang tepat dalam menyelasaikan masalah ekonomi.

\section{Pesantren}

Kata pesantren berasalkan dari kata "santri", huruf pertama dari kata tersebut diakhiri dengan "pe" dan akhiran "an" menunjukkan lokasi, sehingga artinya adalah lokasi dimana siswa tersebut berada. Terkadang pesantren dianggap sebagai gabungan dari kata "santri" (orang baik) dan suku kata "tra" (suka menolong), sehingga kata pesnatren dapat dipahami sebagai tempat untuk menerima pendidikan manusia yang baik. (Kholili, 2012; Toni, 2016; A. F. Zarkasyi, 1998). Menurut Kamus Besar Bahasa Indonesia (KBBI) pondok pesantren berasal dari dua kata yaitu pondok dan pesantren. Pesantren adalah tempat mengaji dan mendalami agama Islam, sedangkan pondok adalah asrama tempat santri belajar mengaji. (Badan Pengembangan dan Pembinaan Bahasa, 2017).

Dhofier dalam Hamzah (2014) menyatakan bahwa dengan menekankan pentingnya keragaman akhlak sebagai pedoman perilaku sehari-hari, maka pesantren diartikan sebagai lembaga pendidikan Islam tradisional untuk belajar, memahami, menghayati dan mengamalkan ajaran Islam (Hamzah, 2014). Mastuhu (1994) mendefinisikan pondok pesantren sebagai lembaga Islam tradisional yang bertujuan untuk memahami, menghayati dan mengamalkan ajaran Islam dengan menekankan pentingnya akhlak agama dalam kehidupan sehari-hari (Mastuhu, 1994). 
Nasir dalam Priyatna mendefinisikan pondok pesantren sebagai lembaga keagamaan yang menyelenggarakan pendidikan dan pengajaran, serta pengembangan dan penyebarluasan ilmu agama Islam. Azyumardi Azra dalam Herryudanta menyampaikan bahwa pesantren Secara terminologis dapat dijelaskan pendidikan pesantren adalah tempat dimana estorik (penghayatan secara lahir) diajarkan (Heriyudanta, 2016). Arifin mendefinisikan pesantren sebagai lembaga pendidikan agama Islam yang terus berkembang dan diakui masyarakat sekitar, serta memiliki sistem pesantren (kampus) yang menerima pendidikan agama melalui sistem pengajian atau madrasah. Kedaulatan yang sepenuhnya dipimpin oleh satu orang atau beberapa kyai memiliki pesona dan kemandirian dalam segala hal (Hamzah, 2014). Lebih lanjut, pesantren merupakan lembaga/ instansi pendidikan swadana dan swadaya, swadana diartikan mampu menopang dengan dana sendiri dan swadaya diartikan mampu berdaya saing tanpa tergantung dengan intansi lainnya (Nugraha, 2018; Susilo, 2016).

\section{Perguruan Tinggi Pesantren Gontor}

Perguruan tinggi di Pesantren Gontor memiliki nama resmi Universitas Darussalam Gontor. Universitas Darussalam Gontor diresmikan pada tanggal 4 Juli 2014 dengan SK Pendirian Kementerian Pendidikan dan Kebudayaan Republik Indonesia No. 197/E/O/2014 (Universitas Darussalam Gontor, 2018a). Universitas Darussalam Gontor (UNIDA) adalah perguruan tinggi yang dinaungi oleh Pondok Modern Darussalam Gontor yang berada di kota Ponorogo Provinsi Jawa Timur. UNIDA berawal dengan nama Institut Pendidikan Darussalam (IPD) yang didirikan oleh K.H. Imam Zarkasy pada tahun 1985 (Pondok Modern Darussalam Gontor, 2017). Pada tahun 1994, IPD berganti nama menjadi Institut Studi Islam Darussalam (ISID) yang terdiri dari tiga fakultas bidang dirosat Islamiyah, yaitu; Fakultas Ushuluddin, Fakultas Syariah dan Fakultas Tarbiyah. Saat ini, UNIDA menambah empat fakultas baru, yaitu; Fakultas Ekonomi dan Manajemen, Fakultas Humaniora, Fakultas Sains dan Teknologi, dan Fakultas Ilmu Kesehatan (Universitas Darussalam Gontor, 2018b).

UNIDA memiliki visi menjadi universitas bersistem pesantren yang bermutu dan berarti, sebagai pusat pengembangan ilmu pengetahuan yang berorientasi pada islamisasi ilmu pengetahuan kontemporer dan sebagai pusat kajian bahasa AlQur'an untuk kesejahteraan umat manusia. Salah satu misi UNIDA adalah menyelenggarakan pendidikan, pengajaran, penelitian, dan pengabdian kepada masyarakat dalam kerangka islamisasi ilmu pengetahuan kontemporer dan pengembangan bahasa Al-Qur'an (Universitas Darussalam Gontor, 2018c). Pengembangan ilmu pengetahuan bersistem pesantren merupakan landasan pembentukan perguruan tinggi pesantren, sehingga menjadi sebuah intistusi pendidikan yang mencetak lulusan yang literated terkait ilmu agama, pengetahuan sains dan teknologi. 
Fakultas Ekonomi dan Manajemen (FEM) merupakan salah satu fakultas baru yang dibentuk pada tahun 2014. FEM memiliki dua program studi, yaitu; ekonomi Islam dan Manajemen. Salam satu visi fakultas ini adalah menjadi fakultas unggulan dalam pengembangan ilmu ekonomi dan ilmu manajemen di tahun 2030. FEM memiliki kurikulum gabungan antara ilmu ekonomi dan ilmu ekonomi Islam, sehingga bercita-cita untuk menghasilkan lulusan bersaing secara nasional. UNIDA bekerja sama dengan FEM dalam mengembangan ilmu ekonomi Islam dengan membentuk Center of Is/maic Economics Studies (CIES) pada tahun 2019 dan menerapkan kurikulum pada unit usaha yang dikelola oleh mahasiswa dikenal dengan naman Unit Usaha UNIDA (U3). U3 dilandasi dari dana wakaf yang dikembangkan menjadi unit usaha. Pada awal ISID menjadi UNIDA, U3 hanya memiliki dua unit usaha yaitu kantin dan fotokopi. Akhir tahun 2019, U3 memiliki 20 unit usaha. U3 melibatkan 38 mahasiswa untuk ikut andil dalam mengelola setiap unit usaha (Syamsuri, 2020; Umam, 2020; Zarkasyi et al., 2016).

Perkembangan UNIDA, FEM dan U3 merupakan capaian perguruan tinggi pesantren dalam mengetahui, memahami, dan menerapkan "melek" ekonomi. Senada dengan penyamapain Rektor UNIDA Prof. K.H. Amal Fathullah Zarkasy, M.A. bahwa empat fungsi utama perguruan tinggi pesantren, yaitu; 1) Perguruan tinggi pesantren sebagai pusat pengkaderan pemikir-pemikir agama (Center of Excellence); 2) Perguruan tinggi pesantren adalah institusi yang mencetak sumber daya manusia (Human Resource); 3) Perguruan tinggi pesantren sebagai lembaga yang mempunyai kekuatan melakukan pemberdayaan pada masyarakat (Agent of Development); dan 4) Perguruan tinggi pesantren merupakan bagian yang terlibat dalam proses perubahan sosial (Social Change) (Zarkasyi, 2019). Perguruan tinggi pesantren berperan sebagai institusi yang mencetak sumber daya manusia unggul dalam menghadapi tantangan zaman, "melek" ekonomi dan terlibat dalam perubahan sosial. Perkembangan Unit Usaha UNIDA Gontor digambarkan pada Gambar 1 yang menunjukkan perkembangan U3 yang signifikan dalam kurun waktu lima tahun terakhir.

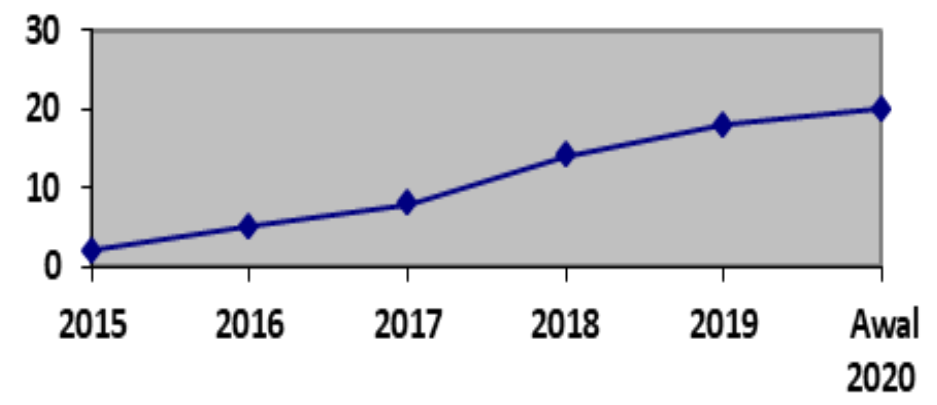

Gambar 1. Perkembangan Unit Usaha UNIDA Gontor

Sumber: Syamsuri, 2020 


\section{METODE PENELITIAN}

Penelitian ini merupakan penelitian kualitatif deskriptif. Data diperoleh dengan menggambarkan keadaan subjek atau objek berupa lembaga, masyarakat dan yang lainnya berdasarkan fakta-fakta dan kondisi yang tampak atau apa adanya saat ini (Moleong, 1989). Objek penelitian ini adalah Universitas Darussalam Gontor yang memiliki sistem perguruan tinggi pesantren. Sumber data penelitian ini terdiri dari data primer dan data sekunder. Data primer didapatkan dari hasil wawancara, observasi dan dokumentasi, sedangkan data sekunder didapatkan dari buku, jurnal, majalah, dan Koran terkait objek penelitian (Agusta, 2003). Teknik analisis data yang digunakan dalam penelitan ini adalah deskriptif informatif, yaitu data penulisan didapatkan dari beberapa informasi dan teori akurat yang mendukung.

\section{HASIL DAN PEMBAHASAN}

\section{Peran UNIDA Gontor dalam Penerapan “Melek" Ekonomi Islam}

UNIDA Gontor sebagai perguruan tinggi pesantren mendorong mahasiswa untuk menjadi "mundziru-I-qoum" sebagai garda terdepan peradaban Islam (Sahal, 2019). Pengembangan literasi ekonomi mahasiswa didorong oleh institusi dalam berbagai kegiatan kampus. Peneliti menemukan dua metode penerapan dan pengembangan literasi ekonomi, yaitu metode akademik dan non akademik. Penerapan literasi ekonomi diselenggarakan dalam sistem perguruan tinggi pesantren, sehingga "melek" ekonomi masuk ke dalam setiap aktivitas keilmuwan, agama, dan kewirausahaan. Sistem perguruan tinggi pesantren sangat mendukung pengembangan literasi ekonomi karena dilandasi swadaya dan swadana oleh setiap masyarakat di dalamnya.

Metode penerapan literasi ekonomi terbagi menjadi dua metode, yaitu metode akademik dan metode non-akademik. Metode akademik dimulai dengan kegiatan harian, mingguan, bulanan, maupun per semester. Pada kegiatan harian, mahasiswa UNIDA Gontor disuguhkan oleh kurikulum berbentuk ilmu ekonomi pengantar, mikro ekonomika dan makro ekonomika (Umam, 2020). Tidak hanya di dalam kelas, mahasiswa UNIDA Gontor dididik untuk berdikari dan mandiri dalam sistem asrama. Pada kegiatan mingguan, mahasiswa UNIDA Gontor disuguhkan kajian rutin mingguan yang diadakan oleh Kelompok Studi Ekonomi Islam (KSEI) dalam menambah pengetahuan dan pemahaman dalam diskusi ilmu ekonomi (Huda, 2020). Selain KSEI yang diikuti, Himpunan Mahasiswa program studi ekonomi Islam menyelenggarakan kajian mingguan pada hari Rabu setelah shalat Isya' yang diawasi dan dibimbing oleh dosen dan mahasiswa pascasarjana. Pada kegiatan per semester, UNIDA Gontor mengadakan kompetisi antar internal kamus maupun eksternal kampus untuk meningkatkan kemampuan dan pengetahuan Mahasiswa terkait ilmu ekonomi dan isu-isu ekonomi terkini. UNIDA Gontor aktif dalam mengadakan seminar dan workshop terkait perpajakan, kebanksentralan, zakat, infak, shadaqah, dan wakaf bekerjasama dengan BI institute, OJK, Baznas, YDSF dan 
intitusi terkait lainnya. Di sisi lain, UNIDA Gontor memiliki institusi yang fokus terhadap kajian ilmu ekonomi Islam dan ziswaf yaitu Central of Islamic Economics Studies (CIES), Laziswaf UNIDA Gontor, dan International Center Awqaf Studies (ICAS).

Metode pengembangan literasi ekonomi UNIDA Gontor lainya adalah Metode non-akademik. Mahasiswa UNIDA Gontor didorong untuk mengembangkan dan menerapkan ilmu ekonomi dalam aktivitas ekonomi sehari-hari, serta diikutsertakan dalam pengelolaan lembaga-lembaga di bawah naungan universitas dan pondok pesantren, seperti Lembaga amil zakat, infaq, shadaqah dan wakaf (Laziswaf) UNIDA Gontor, Baitul Maal wat Tamwil (BMT) Gontor, Koperasi Pesantren (Kopontren) Latansa Gontor, dan U3. Kegiatan setiap instansi di atas memberikan dampak positif terhadap pengembangan dan penerapan ilmu ekonomi dan kewirausahaan mahasiswa UNIDA Gontor, sehingga lulusan perguruan tinggi pesantren tidak hanya menguasai ilmu ekonomi, akan tetapi alumni perguruan tinggi pesantren mampu mengaplikasikan teori ekonomi di dalam kehidupan bermasyarakat.

Perguruan tinggi pesantren memiliki keunggulan dengan sistem asrama, sehingga keberadaan Rektor, Dekan, serta pejabat fungsionaris universitas, dosen dan mahasiswa dalam satu komplek yang sama. Sistem asrama memiliki kelebihan dalam konektivitas antara masyarakat di dalamnya. Literasi menjadi fokus pembahasan di dalamnya, bukan hanya sekedar satu bidang keilmuan melainkan dari berbagai bidang, salah satunya ialah ilmu ekonomi. Perguruan tinggi pesantren mampu menerapkan dan mengembangkan tingkat literasi eknomi mahasiswanya dengan mengikutsertakan mahasiswa ke dalam pengelolaan unit usaha, sehingga mahasiswa mendapatkan ilmu ekonomi bukan sekedar teori, namun dapat diaplikasikan di dalam unit usaha. Hal ini diharapkan mampu memberikan bekal hidup dan keahlian bagi para mahasiswa yang ikut mengelola unit usaha.

\section{SIMPULAN}

Perguruan tinggi pesantren sangat berperan dalam penerapan dan pengembangan literasi ekonomi mahasiswanya, dengan beberapa peran, antara lain sebagai institusi pendidikan yang mengubah orientasi ekonomi masyarakat yang semula bertujuan untuk memuaskan keinginan, menjadi "cukup" dengan memenuhi kebutuhan. Selain itu, perguruan tingi pesantren sebagai institusi pendidikan yang mengubah gaya hidup yang konsumeris, menjadi pola hidup yang moderat. Perguruan tinggi pesantren juga berperan sebagai institusi pendidikan yang membingkai aktivitas ekonomi manusia modern dalam rangka ta'abbudi (ibadah) yang semula hanya sebatas dalam bingkai memuaskan kebutuhan jasmani. Lebih lanjut perguruan tinggi pesantren berperan sebagai institusi pendidikan yang mengubah orientasi profit-oriented dan utility, menjadi orientasi maximizing maslahah. Perguruan tinggi pesantren juga memiliki andil sebagai Institusi pendidikan yang menerapkan metode pembelajaran ekonomi secara drilling. Lebih dari itu, perguruan tinggi pesantren juga berperan penting sebagai institusi 
pendidikan yang menerapkan literasi ekonomi bukan sebatas menggunakan metode akademik, akan tetapi menggunakan metode non-akademik. Signifikansi penelitian ini adalah integrasi kegiatan keagamaan dan ekonomi di pesantren dapat dijadikan sebagai role model dalam strategi peningkatan literasi ekonomi berbasis perguruan tinggi pesantren.

\section{DAFTAR PUSTAKA}

Agusta, I. (2003). Teknik Pengumpulan dan Analisis Data Kualitatif. Litbang Pertanian.

Amalia, Y. (2017). Pengaruh hedonic shopping motivations dan faktor demografis terhadap impulsive buying pengunjung Mal [UIN Syarif Hidayatullah]. http://103.229.202.68/dspace/handle/123456789/36977

Amelia, P. (2018). Tingkat Literasi Ekonomi di Kalangan Pengusaha Mikro Kecil di Kecamatan Kota Gede Yogyakarta. Universitas Sanata Dharma.

Badan Pengembangan dan Pembinaan Bahasa. (2017). KAMUS BESAR BAHASA INDONESIA (KBBI) (5th ed.). BADAN PENGEMBANGAN DAN PEMBINAAN BAHASA KEMDIKBUD.

Basyit, A. (2017). Pembaharuan Model Pesantren: Respon Terhadap Modernitas. Kordinat | Jurnal Komunikasi Antar Perguruan Tinggi Agama Islam, 16(2). https://doi.org/https://doi.org/10.15408/kordinat.v16i2.6444

Hamzah, S. H. (2014). Perkembangan Pesantren di Indonesia (Era Orde Lama, Orde Baru, Reformasi). SYAMIL: Jurnal Pendidikan Agama Islam (Journal of Islamic Education), 2(1), 14. https://doi.org/10.21093/sy.v2i1.490

Heriyudanta, M. (2016). Modernisasi Pendidikan Pesantren Perspektif Azyumardi Azra. MUDARRISA: Jurnal Kajian Pendidikan Islam, 8(1). https://doi.org/https://doi.org/10.18326/mdr.v8i1.145-172

Huda, M. (2020). Interview.

Jappelli, T. (2010). Economic Literacy: An International Comparison. The Economic Journal, 120(548), F429-F451. https://doi.org/10.1111/j.14680297.2010.02397.x

Kholili, H. (2012). Pondok Pesantren Dan Pengembangan Potensi Dakwah. Jurnal Dakwah, 13(2).

Khomsiyatun, U. (2018). Pembelajaran Kreatif Berbasis Literasi Bahasa Menumbuhkan Anak yang Cerdas dan Kreatif. INSANIA : Jurnal Pemikiran Alternatif Kependidikan, 23(2). https://doi.org/https://doi.org/10.24090/insania.v23i2

Kusniawati, M. (2016). Pengaruh status sosial ekonomi orang tua dan literasi ekonomi terhadap perilaku konsumsi siswa kelas X IPS di SMA Negeri 2 Tuban. Jurnal Pendidikan Ekonomi (JUPE), 4(3).

Ma'arif, S. (2011). DINAMIKA PESANTREN KONTEMPORER. Millah, 11(1), 29-49. https://doi.org/10.20885/millah.vol11.iss1.art2 
Margaretha, F., \& Pambudhi, R. A. (2015). Tingkat Literasi Keuangan Pada Mahasiswa S-1 Fakultas Ekonomi. Jurnal Manajemen Dan Kewirausahaan, 17(1).

Mastuhu. (1994). Dinamika Sistem Pendidikan Pesantren. INIS.

Mathews, A. J., Chute, A., \& Cameron, C. A. (1986). Meeting the Literacy Challenge: A Federal Perspective.

Miller, J. W., \& McKenna, M. C. (2016). World Literacy (1st ed.). Routledge. https://doi.org/10.4324/9781315693934

Moleong, L. J. (1989). Metodologi Penelitian Kualitatif. Remaja Rosda Karya.

Nugraha, A. L. (2018). Islamic Business Ethics and Islamic Microfinance in Pesantren Gontor. Shirkah: Journal of Economics and Business, 2(1). https://doi.org/10.22515/shirkah.v2i1.28

Nugraha, A. L., Sunjoto, A. R., \& Susilo, A. (2019). Signifikansi Penerapan Literasi Ekonomi Islam di Perguruan Tinggi: Kajian Teoritis. Islamic Economics Journal, 5(1), 143-162.

Padmarini, R. R. U. (2002). Dampak Pemberlakuan Ecolabelling oleh Negara-negara Maju Terhadap Ekspor Indonesia [Universitas Airlangga]. http://repository.unair.ac.id/46804/

Prayogo, S. (2020). Indonesia Krisis Literasi. 26 July. https://www.bukabaca.id/indonesia-krisis-literasi/

Priyatna, M. (2017). Manajemen Pembelajaran Program Kulliyatul Mu'allimin alIslamiyah (KMI) di Pondok Pesantren Modern al-Ihsan Baleendah Bandung. Edukasi Islami : Jurnal Pendidikan Islam, 6(11), 22. https://doi.org/10.30868/ei.v6i11.93

Puspita, G. A., \& Irwansyah, I. (2018). Pergeseran Budaya Baca dan Perkembangan Industri Penerbitan Buku di Indonesia: Studi Kasus Pembaca E-Book Melalui Aplikasi iPusnas. BIBLIOTIKA: Jurnal Kajian Perpustakaan Dan Informasi, 2(1), 13-20. https://doi.org/10.17977/um008v2i12018p013

Reder, S. (2010). Adult Literacy Development and Economic Growth. https://files.eric.ed.gov/fulltext/ED512441.pdf

Rizal, A., Fauziyah, N. E., Ma'ruf, A., \& Susilo, A. (2020). Integrating Zakah and Waqf for Developing Islamic Economic Boarding School (IEBS) Project in Indonesia. Journal of Islamic Economics and Philanthropy, 3(2). https://doi.org/10.21111/jiep.v3i02.4577

Romdhoni, A. (2013). Al-Qur'an dan Literasi: Sejarah Rancang-Bangun Ilmu-ilmu Keislaman. Literatur Nusantara.

Sahal, H. A. (2019). Pidato Pekan Perkenalan Universitas Darussalam Gontor. Gontor.

Saifudin, M. F., \& Safitri, I. A. (2015). Optimalisasi Pembelajaran Bahasa Indonesia Melalui Budaya Literasi di Sekolah Dasar.

Sina, P. G. (2012). Analisis Literasi Ekonomi. Jurnal Economia, 8(5). 
Stern, G. H. (2002). Economic literacy leads to better grasp of public policy issues. The Region, Federal Reserve Bank of Minneapolis, 16, 2-5.

Sugrue, M. (2017). Literacy, Language, and Learning (L3) Initiative. U.S. Agency for International Development. https://www.edc.org/literacy-language-andlearning-13-initiative\#challenge

Susilo, A. (2016). Kontribusi Waqf Gontor Terhadap Kesejahteraan Masyarakat Desa Gontor. Islamic Economics Journal, 2(1). https://doi.org/10.21111/iej.v2i1.967

Syamsuri. (2020). Interview.

Literacy Rates Continue to Rise from One Generation to the Next, Pub. L. No. FS/2017/LIT/45

http://uis.unesco.org/sites/default/files/documents/fs45-literacy-ratescontinue-rise-generation-to-next-en-2017.pdf

Toni, H. (2016). Pesantren Sebagai Potensi Pengembangan Dakwah Islam. Jurnal Dakwah Dan Komunikasi, 1(1).

Umam, K. (2020). Interview.

Universitas Darussalam Gontor. (2018a). History of UNIDA Gontor. UNIDA Gontor. http://unida.gontor.ac.id/history/\#top

Universitas Darussalam Gontor. (2018b). Undergraduate Program. UNIDA Gontor.

Universitas Darussalam Gontor. (2018c). Visi, Misi, \& Tujuan. UNIDA Gontor. http://unida.gontor.ac.id/visi-misi-tujuan/

Zarkasyi, A. F. (1998). Pondok Pesantren sebagai Lembaga Pendidikan dan Dakwah. In A. Sasono, D. Hafidhuddin, \& A. M. Saefuddin (Eds.), Solusi Islam atas problematika umat : ekonomi, pendidikan, dan dakwah. Gema Insani Pers.

Zarkasyi, A. F. (2019). Pidato Pekan Perkenalan Universitas Darussalam Gontor. Gontor.

Zarkasyi, H. F., Lahuri, S., Umam, K., \& Cahyo, E. N. (2016). Curriculum Design of Master Program on Islamic Economics in Indonesian, Pakistan, Turkish, and Malaysian Universities. TSAQAFAH Journal of Islamic Civilization, 12(1). 